Tersedia Online di http://journal.unismuh.ac.id/index.php/otoritas

Otoritas : Jurnal Ilmu Pemerintahan, 6 (1), April 2016, 50-59

\title{
Dinamika Gerakan Pembentukan Daerah Otonom Baru Kabupaten Mandau-Riau
}

\author{
Muhammad Ashsubli*) \\ Sekolah Tinggi Agama Islam Negeri Bengkalis, Jalan Lembaga - Senggoro, Bengkalis, Riau, Indonesia
}

Diterima : 6 Februari 2016; Disetujui : 29 Maret 2016; Dipublikasikan 14 April 2016

\begin{abstract}
The purpose of this study was to identify and analyze the dynamics of the movement forming a new autonomous region in the district of Mandau. The method used in this research is qualitative descriptive analysis. Sources of data in this study are primary data the authors obtained from interviews with informants and secondary data obtained from the nature of the documents, archives, and other results are available. The results found that the dynamics of the social movements of tangible movement collectivity of people in it to carry or resist change. All that could happen due to the nature of the people themselves who want change it is marked on the organizing societies Mandau and Pinggir were struggling collectively to realize combustion Mandau regency or Duri City.
\end{abstract}

Keywords: movement; autonomy; redistricting

\begin{abstract}
Abstrak
Tujuan dari penelitian ini adalah untuk mengetahui dan menganalisa dinamika gerakan pembentukan daerah otonomi baru di Kabupaten Mandau. Metode yang digunakan pada penelitian ini adalah Analisis Deskriptif Kualitatif. Sumber data dalam penelitian ini adalah data primer yang penulis peroleh dari hasil wawancara dengan informan serta data sekunder yang didapat dari dokumendokemen, arsip-arsip, dan hasil lain yang tersedia. Hasil penelitian menemukan adanya dinamika gerakan sosial yang berwujud gerakan kolektifitas orang-orang di dalamnya untuk membawa atau menentang perubahan. Semua itu bisa terjadi disebabkan sifat masyarakat itu sendiri yang menginginkan perubahan hal ini ditandai dari pengorganisasian masyarakat-masyarakat Mandau dan Pinggir yang berjuang secara kolektif untuk mewujudkan pemekaran daerah Kabupaten Mandau atau Kota Duri.
\end{abstract}

Kata kunci : gerakan; otonomi; pemekaran

Cara Penulisan Sitasi : Ashsubli, M. (2016). Dinamika Gerakan Pembentukan Daerah Otonom Baru Kabupaten Mandau-Riau. Otoritas : Jurnal Ilmu Pemerintahan, 6(1), 50-59.

*)Penulis Korespondensi.

E-Mail : subli.stain@gmail.com

Copyright (C) 2016, Otoritas : Jurnal Ilmu Pemerintahan, p-ISSN: 2088-3706, e-ISSN: 2502-9320 
Tersedia Online di http://journal.unismuh.ac.id/index.php/otoritas

Otoritas : Jurnal Ilmu Pemerintahan, 6 (1), April 2016, 51

\section{Pendahuluan}

Gerakan sosial lahir dari situasi yang dihadapi masyarakat karena adanya ketidak adilan dan sikap sewenangwenang terhadap rakyat. Lebih lanjut Mirsel (2006) menyimpulkan bahwa masyarakat tersebut cenderung tidak diakui sebagai sesuatu yang berlaku umum secara luas dan sah di dalam suatu masyarakat yang akhirnya timbul rasa ketidakadilan.

Otonomi daerah didasarkan kepada kebebasan untuk dapat menjadikan daerah menjadi lebih maju karena pemerintahan daerah memiliki kemampuan dan kesempatan untuk menjalankan pembangunan sesuai dengan kondisi dan kebutuhan daerah.

Melalui pemekaran daerah, maka tata kelola pemerintahan, kualitas layanan kepada masyarakat, kedekatan dan ketepatan waktu pelayanan publik akan semakin baik. Hal ini karena pemekaran bertujuan untuk meningkatkan kesejahteraan masyarakat, dimana birokrasi yang ada menjadi lebih pendek dan sederhana serta semua sumber data lokal dapat dinikmati, dikelola langsung bagi masyarakat. Investasi yang masuk juga bisa langsung ke daerah, pemerintah dapat menggali potensi daerahnya secara optimal, daerah-daerah yang sebelumnya tidak tersentuh menjadi prioritas utama, terutama untuk kemajuan pembangunan sampai di tingkat desa.

Pemekaran juga bertujuan untuk mendekatkan pusat pemerintahan daerah ke masyarakat setempat sehingga segala urusan pelayanan pemerintah dapat diselenggarakan sevara berkualitas. Pada hakikatnya pemekaran daerah bukanlah hal yang diharamkan dan ditabukan asalkan dalam bingkai Negara Kesatuan Republik Indonesia. (Kaho, 2012).

Selain itu, pemekaran harus dilakukan dengan alasan yang jelas agar mampu mandiri setelah dilepaskan dari induk pemerintahannya semula. Dengan kemandirian itulah wilayah pemekaran akan menghasilkan kemajuan dan perbaikan kehidupan rakyat daerahnya, memudahkan akses transportasi dan kedekatan pelayanan bidang pemerintahan, memperlancar interaksi dan hubungan dengan wilayah yang selama ini tidak terjangkau serta berpeluang untuk meningkatkan pemerataan pembangunan.

Sebagai konsekwensi dari keinginan untuk mendistribusikan kemakmuran masyarakat secara lebih merata, maka pemekaran daerah menjadi sebuah yang niscaya, terlebih lagi di era globalisasi ketika terjadi perpindahan invenstasi, lintas batas orang, barang dan jasa yang didukung oleh kemajuan transportasi, teknologi informasi dan komunikasi.

Pemekaran daerah harus dilihat sebagai keinginan politik yang tulus warga masyarakat mempunyai pemerintahan daerah sendiri sehingga dapat lebih baik mengurus rakyatnya. Pemekaran merupakan produk dari digunakannya otonomi daerah dalam pemerintahan daerah dan demokratisasi. Dengan demikian pemekaran daerah merupakan wujud dari pemenuhan aspirasi rakyat yang merupakan dasar dari demokrasi itu sendiri.

Berbagai kajian terdahulu tentang pemekaran daerah salah satunya dilakukan oleh Rifdan (2010) tentang implementasi kebijakan pemekaran daerah dalam mendukung integrasi nasional menunjukan bahwa tahapan implementasi kebijakan pemekaran daerah Kabupaten Luwu Timur telah dilaksanakan sesuai ketentuan perundang-undangan yang mengatur Faktor-faktor yang mendukung implementasi kebijakan pemekaran daerah adalah adanya sumber daya alam yang potensial, penanaman modal (investasi), infrastruktur transportasi dan komunikasi, keterbukaan terhadap pihak luar dan dukungan publik (masyarakat). Wujud implementasi kebijakan di bidang politik meliputi pembangunan berbagai struktur dan infrastruktur politik, adanya 
Tersedia Online di http://journal.unismuh.ac.id/index.php/otoritas

Otoritas : Jurnal Ilmu Pemerintahan, 6 (1), April 2016, 52

transparansi dan akuntabilitas pemerintahan, peningkatan peran dan partisipasi aktif masyarakat dalam proses pengambilan keputusan, kebebasan berpolitik dan berorganisasi, penegakan supremasi hukum dan hak asasi manusia, serta terwujudnya stabilitas politik.

Di bidang ekonomi meliputi percepatan pembangunan struktur dan infrastruktur ekonomi, pengelolaan potensi sumber daya alam dan peningkatan lapangan kerja, pendapatan perkapita, Produk Domestik Regional Bruto serta Pendapatan Asli Daerah.

Di bidang sosial budaya meliputi pembinaan kerukunan hidup antar warga masyarakat, berkurangnya kesenjangan sosial budaya, peningkatan kualitas pendidikan, kemampuan penataan wilayah dan pemberdayaan kelompok masyarakat ter.pencil, pengembangan nilai-nilai budaya lokal dan pemanfaatan kearifan lokal dalam menyelesaikan berbagai masalah. Implementasi kebijakan pemekaran daerah mendukung integrasi nasional karena terwujudnya stabilitas kehidupan bermasyarakat, adanya kemudahan memperoleh pelayanan publik, meningkatnya kualitas pelayanan publik, dan terwujudnya integrasi dalam kehidupan bermasyarakat.

Kemudian Kurniawati melihat dari segi pengaruh dari sebuah pemekaran berdasarkan hasil analisis yang diperoleh dapat diketahui bahwa pemekaran daerah belum tentu dapat meningkatkan kesejahteraan masyarakat daerah otonom baru dilihat dari pertumbuhan ekonomi, pelayanan publik, dan kondisi sosial ekonomi masyarakatnya. Secara umum, sebagian besar DOB mengalami laju pertumbuhan yang lebih pesat dibandingkan daerah induk dan rata-rata nasional namun belum menunjukkan perkembangan dilihat dari penyediaan pelayanan publik dan kondisi sosial ekonomi masyarakat di daerah otonom baru.

Dari segi dampak pemekaran Su- santi (2014) menunjukkan setelah pemekaran ada pergeseran struktur ekonomi di Kabupaten Lampung Utara yaitu dari pertanian menjadi industri pengolahan, kesejahteraan Kabupaten Lampung Utara mengalami peningkatan. Hasil penghitungan menggunakan alat AHP yaitu para pakar berpendapat bahwa dampak yang paling utama dari pemekaran yaitu kesejahteraan ekonomi Sementara masyarakat merasakan setelah pemekaran ternyata peningkatan kualitas infrastruktur lebih dominan daripada kesejahteraan ekonomi.

Dari berbagai sudut padang yang telah dikemukakan maka belum diindentifikasi sebuah uraian mendalam mengenai dinamika suatu perubahan social yang terjadi dalam suatu daerah pemekaran dimana masyarakat berhak untuk menentukan nasibnya sendiri, mendapatkan pelayanan pemerintahan dan mendapatkan kesejahteraan dalam kerangka Negara Kesatuan Republik Indonesia, seperti yang dilakukan masyarakat yang berada di Kecamatan Mandau dan Kecamatan Pinggir untuk membentuk kabupaten sendiri mekar dari Kabupaten Bengkalis. Semula Kabupaten Bengkalis sangat luas cakupannya, diantaranya, Kabupaten Rokan Hilir, Kabupaten Siak, Kota Dumai, dan Kabupaten Kepulauan Meranti. Gerakan pembentukan Kabupaten Mandau ini sesungguhnya telah berlangsung lama. Secara umum, gelombang perjuangan pembentukan Kabupaten Mandau sudah dilakukan setelah era reformasi 1999.

Merujuk pada deskriptif di atas, maka penulis sebagai akademisi tertarik untuk mengetahui dan melihat suatu sudut nyata perubahan sosial yang terjadi melalui gerakan sosial, khususnya dari aktifitas Dewan Presidium Masyarakat Kabupaten Mandau (DPMKM) Komite Persiapan Pembentukan Kabupaten Mandau (KP2KM) yang menjadi motor penggerak sekaligus agen perubahan terjadinya gerakan sosial demi mendapatkan

Copyright (C) 2016, Otoritas : Jurnal Ilmu Pemerintahan, p-ISSN: 2088-3706, e-ISSN: 2502-9320 
perubahan yang memang telah diidamidamkan oleh masyarakat Mandau melalui perwujudan terpisahnya Mandau dari Kabupaten induknya yaitu Bengkalis. Hal ini mengartikan bahwa tujuan dari penelitian ini adalah untuk mengetahui dan menganalisa dinamika gerakan pembentukan daerah otonomi baru di Kabupaten Mandau.

\section{Metode Penelitian}

Lokasi penelitian ini dilakukan di. Kabupaten Mandau dengan berfokus pada Dinamika Pembentukan Daerah Otonom Baru yang ada didalamnya dalam kurung waktu 1999-2014. Metode penelitian pada dasarnya merupakan cara ilmiah untuk mendapatkan data dengan tujuan dan kegunaan tertentu Sugiyono (2013). Oleh karena itu jenis penelitian ini adalah penelitian kualitatif, artinya suatu jenis penelitian yang berusaha memberikan penjelasan dengan gambaran mengenai berbagai macam data yang telah dikumpulkan dari objek penelitian yang berkaitan dengan dinamika pembentukan daerah otonom baru di Kabupaten Mandau.

Metode yang digunakan pada penelitian ini adalah Analisis Deskriptif Kualitatif yaitu menggambarkan keadaan objek penelitian sesuai dengan data dan fakta yang ditemukan. Kemudian yang menjadi sumber data dalam penelitian ini adalah data primer yang penulis peroleh dari hasil wawancara dengan informan serta data sekunder yang didapat dari dokumen-dokemen, arsip-arsip, dan hasil lain yang tersedia.

\section{Hasil dan Pembahasan}

Berdasarkan hasil penelusuran dokumen Mandau adalah nama anak sungai yang bermuarake sungai Siak membujur dari Timur ke Barat akhirnya menjadi nama suatu daerah yaitu daerah Mandau yang di Zaman kerajaan Siak disebut Ondor Distrik Mandau. Daerah yang memiliki hukum sendiri disahkan oleh sultan Siak. Bertitik tolak dari sinilah kita tinjau sejarah Mandau ini sebelum kerajaan Siak (1723), Mandau sudah dihuni oleh manusia dengan sebutan Suku Ando NanSembilanPuluhSembilan yang kemudian resmi menjadi suku Mandau.

Suku Anda Nan Sembilan Puluh Sembilan ini diperintahkan salah seorang penghulu Tuk Penghulu dengan di bawah naungan kerajaan Koto Pait berkedudukan di beringin. Kerajaan ini berdiri sebelum Kerajaan Siak dan Kerajaan Gasib. Dengan istilah Tuk Penghulu Ando siapa saja penghulu di kampung ini tetap bergelar Penghulu Ando yang lamakelamaan menjadi Penghulu Mandau.

Jika ditinjau dalam riwayat ini tanah Mandau diperintah oleh seorang penghulu yaitu Penghulu Mandau. Kejadian ini sebelum Mandau jatuh ke kerajaan Siak. Jadi memang sungai Mandau waktu itu bernama Sungai Kemuning atau Sungai Embun, sungai seakan-akan lengang dan sunyi sebab penduduknya sedikit dan belum pandai membuat sampan atau perahu.

Jadi, kekuasaan penghulu Mandau ini memang luas, misalnya berbatasan langsung dengan distrik Siak, Onder Distrik Tapung, Onder Distrik Tanah Putih, Onder Distrik Bukit Batu. Sungai Kalimunting mulai berfungsi dan dikenal penduduk sebagai hubungan dan tempat mencari kehidupan sehingga sungai ini terkenal dengan nama sungai Mandau di bawah kekuasaan Penghulu Ando yang akhirnya menjadi Penghulu Mandau (Penghulu Puncak).

Jejak sejarah Mandau tidak dapat dipisahkan dari sosok bersahaja yang dikenal sebagai Boedjamg Ganti, Bathin Kampoeng Djamban (Bathin Delapan) onderdistrict Mandau, tahun 1940. Terekam kisah ketika ia mendapatkan gelar Batin Betuah, sempena pertabalan Sri Maharaja Ratu, peresmian ladang minyak Tanjung mempelam dan peresmian los pasar Muara Klantan, Sultan Siak Indrapura berkenan bertitah: 
Tersedia Online di http://journal.unismuh.ac.id/index.php/otoritas

Otoritas : Jurnal Ilmu Pemerintahan, 6 (1), April 2016, 54

"Bujang ganti, akampung awak adalah kampung bertuah, oleh karena itu beta berkenan menagnugerahkan awak kurnia dengan gelar Batin Betuah, di masa akan datang nanti, biji mata hamba rakyatnya segantung menyelai, jaga dan peliharalah kampung awak sebaik-baiknya"

Kelak titah "segantang menyalai" ini memberikan tuah bagi kehidupan masyarakat dan menjadi cikal bakal keramaian dan kelahiran Kota Duri (hari ini), sebab pada tahun 1941 (setahun setealah pemberian gelar batin Betuah) Catatan tentang jejak Jepang di Mandau, hanya tersisa kisah tentang gua Jepang, bekas rel kereta api dan camp Jepang yang hingga kini masih tersimpan, misteri. Setidaknya ada bukti di pemakaman Balai Raja, kompleks Chevron, bernama Monumen Korban Perang Dunia II (Monument of World War II Victims).

Pada awal kemerdekaan tahun 1945, wilayah pulau Sumatera hanya dibagi menjadi 3 daerah tingkat Provinsi, yaitu provinsi Sumatera Barat, Sumatera Tengah dan Sumatera Selatan, sedangkan Sumatera Tengah terdiri dari 3 wilayah Keresidenan, yaitu Keresidenan Sumatera Barat dengan ibukota Bukit Tinggi, Keresidenan Riau dan Keresidenan Jambi.

Melalui UU darurat No. 19 tahun 1957 dan diundagkan dalam UU No. 61/1958 secara resmi terbentuklah Provinsi Sumatera Barat, Riau dan Jambi. Dalam Undang-undang tersebut, wilayah daerah Provinsi Riau meliputi Kabupaten Bengkalis, Kampar, Indragiri, Kepulauan Riau dan Kotapraja Pekanbaru, dengan Tanjung Pinang sebagai ibukota Provinsi Riau. Mr.S.M. Amin diangkat sebagai Februari 1958, kemudian dilantik oleh Mr. Sumarman mewakili Menteri Dalam Negeri pada tanggal 1958.

Melalui Surat Ketetapan Pemerintah Pusat RI No:Des/52/1/44.25, tanggal 20 januari 1959, ibukota Provinsi Riau di Tanjung Pinang dipindahkan ke Kota Pekanbaru. Dalam Penpres No.22 Tahun 1963 tentang liquidasi Daerah-daerah
Keresidenan dan Kewedanan di seluruh Indonesia, maka Bengkalis dibagi menjadi 4 kewedanan dan 11 kecamatan, ketetapan tersebut diberlakukan pada tanggal 25 oktober 1963.

Gerakan pembentukan Kabupaten Mandau ini sesungguhnya telah berlangsung lama. Secara umum, gelombang perjuangan pembentukan Kabupaten Mandau sudah dilakukan setelah era reformasi (1999). Pergerakan pembentukan Kabupaten Mandau pada era reformasi ini sukses mendapatkan dukungan Bupati Kepala Daerah Tingkat II Bengkalis pada tahun 1999. Sebelumnya, di tahun yang sama pada tanggal 21 juni gerakan pembentukan Kabupaten Mandau telah mendapatkan restu oleh Dewan Perwakilan Rakyat Daerah Kabupaten Daerah Tingkat II Bengkalis yang ditandatangani oleh Ketua saat itu Drs. H. Helmy Mat

Kabupaten Mandau pada dasarnya memang layak menjadi daerah otonomi baru, mengingat kondisi geografis di Mandau dan Pinggir sangat luas, disamping sumber daya alam yang dimiliki oleh Kecamatan Mandau dan Kecamatan Pinggir yaitu minyak bumi yang berkisar 1 miliar barel produksi yang memberikan devisa bagi negara serta pajak air bawah tanah yang tetap diperhitungkan dari dari banyaknya pemakaian air untuk steam di Duri Steam Field (DSF). Ladang minyak ini merupakan ladang eksplorasi steam terbesar di dunia.

Secara geografis Mandau dan Pinggir merupakan salah satu kecamatan yang memiliki tempat strategis dan jalur lintas sumatera. Secara keseluruhan Kecamatan Mandau terdiri dari lima belas desa/ kelurahan. Adapun dari seluruh desa/ kelurahan tersebut terdiri dari empat bealas desa dan sembilan kelurahan. Kecamatan Mandau terdiri dari 721 Rukun Tetangga (RT) dan 158 Rukun Warga (RW). Adapun Desa/Kelurahan yang memiiki jumlah RT yang terbanyak adalah Kelurahan Air Jamban sebanyak 115 RT dan Kelurahan Talang Mandi

Copyright (C) 2016, Otoritas : Jurnal Ilmu Pemerintahan, p-ISSN: 2088-3706, e-ISSN: 2502-9320 
Tersedia Online di http://journal.unismuh.ac.id/index.php/otoritas

Otoritas : Jurnal Ilmu Pemerintahan, 6 (1), April 2016, 55

sebanyak 68 RT.

Untuk mengingatkan kembali dinamika dan proses perjuangan yang dilakukan oleh Komite Pembentukan Kabupaten Mandau dengan penuh semangat,kerja keras, berliku, yang diwarnai dengan berbagai ketegangan bahkan aksi unjuk rasa besar-besaran.

Milllestone proses perjuangan ini menampilkan peristiwa yng mengiringi upaya pembentukan Kabupaten Mandau apa adanya, sebab sekecil apapun peran dan sumbangsih masyarakat merupakan bagian yang tidak terpisahkan dari proses perjuangan pembentukan.

Tanggal 16 Mei 1999, merupakan awal perjuangan masyarakat Mandau untuk memperjuangkan Kabupaten Mandau. Diawali dengan peresmian sebuah forum yang mengayomi antar suku dan agama se kecamatan Mandau (termasuk Kecamatan Pinggir). Gubernur H. Saleh Djasit, dan Bupati H. Fadhlah Sulaiman meresmikan Forum Komunikasi antar Suku dan Agama (FKSA). Acara tersebut ditaja untuk menyampaikan sebuah pernyataan sembilan partai politik dan suku-suku yang ada di Duri untuk mendukung pembentukan Kabupaten Mandau.

Satu minggu kemudian, tanggal 24 Mei 1999 Forum Komunikasi antar Suku dan Agama (FKSA), memfasilitasi diadakannya Musyawarah Besar (MUBES) yang dalam kesempatan itu dihadiri oleh tokoh masyrakat, alim ulama, cendekiawan, partai politk, ormas, LSM dan disaksikan oleh camat Mandau Drs. Zulkarnarn. Forum menghasilkan keputusan penting yaitu upaya meningkatkan status Mandau menjadi Kabupaten Mandau, untuk itu dibentuklah Badan Pekerja Peningkatan status Pembantu Wilayah II Kabupaten Bengkalis yang berkedudukan di Duri menjadi Kabupaten Mandau dengan nama Komite Pembentukan Kabupaten Mandau (KPKM).

Setelah terbentuknya badan ini, maka Komite Pembentukan Kabupaten Mandau (KPKM) segera menemu DPRD
Bengkalis untuk meminta dukungan pengusulan peningkatan status Duri menjadi Daerah Otonom. Atas usulan tersebut, Ketua DPRD Tingkat II Bengkalis Drs. H. Helmy Mat menandatangani usulan dari KPKM (21 Juni 1999) sekaligus mendukung sepenuhnya Pembentukan Kabupaten Mandau dan meneruskan ke pihak yang berwenang sesuai ketentuan yang berlaku.

Sebulan kemudian, giliran Bupati Kepala Daerah Tingkat II Bengkalis H. Fadlah Sulaiman, SH menaggapi aspirasi yang datang dari masyarakat untuk membentuk Kabupaten Daerah Tingkat II Mandau yang merupakan bagian dari wilayah Kabupaten Daerah Tingkat II Bengkalis.

Bulan maret 2000, dimasa awal kepemimpinan Drs.Syamsurizal membuat sebuah karya buku berjudul "Riau di Tengah Kancah Millenium" (Kontribusi Pemikiran untuk Pembangunan ke Depan) yang diterbitkan oleh Yayasan Sagang. Buku tersebut tercantum wacana Pemekaran Kabupaten Mandau, yang merupakan gabungan dari kecamatan Mandau dan dan Minas. Penetapan strategis ibukotanya untuk Kabupaten DATI II yang direncanakan itu adalah Kota Duri.

Namun demikian, keadaan berbalik dari kenyataan. Untuk pertama kali $\mathrm{Bu}-$ pati Syamsurizal menyampaikan penolakan pemekaran Mandau secara terbuka kepada masyarakat, ketika dia melantik RY sebagai Camat Mandau. menyampaikan :

"keinginan segelintir orang untuk menjadikan Mandau sebagai Kabupaten adalah suatu yang mustahil, dan Kabupaten Mandau tidak akan pernah ada" (Hasil wawancara SR, 2014)

Berdasarkan hasil wawancara diatas terdapat penyampaian penolakan pemekaran Mandau secara terbuka kepada masyarakat. Sementara itu Pengamat Sosial Mandau AM mengatakan, diakui atau tidak, ditunda atau diajukan, Mandau secara sosial dan politis sangat memenuhi 
Tersedia Online di http://journal.unismuh.ac.id/index.php/otoritas

Otoritas : Jurnal Ilmu Pemerintahan, 6 (1), April 2016, 56

kriteria menjadi sebuah kabupaten, sebagaimana diamanahkan oleh Undangundang. Beliau mengungkapkan:

"melihat kondisi demografis, insfraktruktur, lalu lintas finansial secara kesiapan sumber daya manusia yang ada, adalah naif bila semangat untuk menjadikan Mandau Daerah Otonom menjadi stagnan" (hasil wawancara AM, 2014).

Berdasarkan hasil wawancara diatas dapat diperoleh penjelasan bahwa ada kerinduan masyarakat Mandau untuk menjadi Daerah Otonom Baru dilatar belakangi realitas pembangunan yang tidak berkeadilan, luas wilayah dan jangkauan pelayanan yang sangat jauh. Embrio lahirnya KP2KM adalah sebenarbenarnya semangat kejuangan. Bukan persoalan kalah menang, sebab pemekaran adalah hak masyarakat yang dijamin oleh undang-undang.

Setiap perjuangan pasti memerlukan pengorbanan. Mandau hari ini membutuhkan kekuatan Pilkada Gubernur Riau yang lalu, merupakan sebuah kekuatan baru bagi Masyarakat Mandau. Sebelumnya, H. Annas Maamun menyatakan komitmennya untuk membantu perjuangan Kabupaten Mandau. Setelah H. Annas Maamun terpilih menjadi Gubernur, beliau lebih setuju kalau Duri menjadi KOTA.

Tanggal 3 september 2014 merupakan energi baru bagi masyarakat Duri. Sidang paripurna DPRD Riau mengeluarkan rekomendasi KOTA DURI.Menetapkan lokasi calon ibukota daerah otonom baru Kota Duri adalah Duri, menyetujui bantuan dana untuk mendukung penyelenggaraan pemerintahan calon Ibukota Kota Duri untuk jangka waktu 2 (dua) tahun bertutut-turut terhitung sejak peresmian sebagai Kota Duri. Kesempatan itu, Ketua DPRD Riau, DF mengatakan

"mandau sudah layak jadi Kota, karena pertumbuhan ekonominya yang sudah memadai dan jumlah penduduknya yang sudah banyak" (Hasil Wawancara DF, 2014).

Berdasarkan hasil wawancara diatas dapat dipahami bahwa pro dan Kontra pasti ada, terlebih mereka yang menginkan Kabupaten dan Kota. Namun, Lembaga Adat Melayu Riau (LAMR) Mandau yang dinahkodai ZI berhasil menyatukan seluruh paguyuban di Mandau dan Pinggir. Hal ini tergambar melalui hasil wawancara berikut :

"LAMR Mandau bukan wadah politik, tapi wadah menyatukan seluruh paguyuban, ikatan-ikatan keluarga yang ada di Duri, tidak ada kepentingan LAM dalam pemekaran wilayah ini, kami hanya sebagai jembatan untuk mewujudkan aspirasi masyarakat." (hasil wawancara ZI, 2014).

Dari hasil wawancara diatas dapat diperoleh pemahaman bahwa LAMR) Mandau berhasil menyatukan seluruh paguyuban di Mandau. Sehingga akhirnya dibentuk Susunan pengurusan Panitia Persiapan Pembntukan Kota Duri (P3KD) pun terbentuk dengan menghadirkan seluruh tokoh etnis, ketua ikatan-ikatan keluarga yang ada di kecamatan Mandau dan Pinggir.

Berdasarkan hasil penelitian ini dapat diketahui bahwa Kabupaten Mandau pada dasarnya memang layak menjadi daerah otonomi baru, mengingat kondisi geografis di Mandau dan Pinggir sangat luas, disamping sumber daya alam yang dimiliki oleh Kecamatan Mandau dan Kecamatan Pinggir yaitu minyak bumi yang berkisar 1 miliar barel produksi yang memberikan devisa bagi negara serta pajak air bawah tanah yang tetap diperhitungkan dari dari banyaknya pemakaian air untuk steam di Duri Steam Field (DSF). Ladang minyak ini merupakan ladang eksplorasi steam terbesar di dunia. Secara jumlah penduduk Mandau sudah layak menjadi daerah otonom baru.

Maka dari itu, dipandang perlu 
Tersedia Online di http://journal.unismuh.ac.id/index.php/otoritas

Otoritas : Jurnal Ilmu Pemerintahan, 6 (1), April 2016, 57

untuk mengkaji pemekaran Kabupaten Bengkalis ditinjau dari segi rentang kendali berdasarkan kondisi geografis Kecamatan Mandau dan Kecamatan Pinggir berada jauh dari ibukota kabupaten Bengkalis dengan jarak tempuh lebih kurang lima jam perjalanan melewati jalan bergelombang dan menyeberang laut. Setiap urusan tidak mungkin terselesai dalam satu hari, harus menginap dikarenakan sulitnya untuk menemui pejabat terkait, dan tentu memakan biaya yang tidak sedikit.

Disamping itu melihat dari segi jumlah penduduk, pertumbuhan ekonomi, rentang kendali yang jauh dari Kota Bengkalis dan infrastruktur Mandau sudah sangat memenuhi syarat. Bahkan populasi penduduk di Kecamatan Mandau saja sudah over yang tidak mungkin hanya diawasi oleh seorang camat.

Gerakan Sosial memiliki akar sejarah yang panjang dalam berbagai masyarakat di banyak negara. Gerakan sosial juga merupakan bentuk kolektifitas orang-orang di dalamnya untuk membawa atau menentang perubahan. Semua itu bisa terjadi disebabkan sifat masyarakat itu sendiri yang menginginkan perubahan. Gerakan Sosial merupakan fenomena partisipasi masyarakat. Istilah lain diartikan sebagai instrumen hubungan kekuasaan antara masyarakat (yang cenderung powerless) dengan entitas yang lebih berkuasa (powerful). Gerakan sosial menjadi instrumen menyuarakan kepentingan masyarakat yang berfungsi sebagai Loud Speaker agar dapat didengar.

Sebagai sebuah organisasi Gerakan Sosial, KP2KM, KPKM ataupun P3KD memiliki karakteristik yang sama jika dibandingkan dengan teori gerakan sosial yang telah ada. Anthony Giddens (dalam Putra, 2006) menyatakan Gerakan Sosial sebagai upaya kolektif untuk mengejar kepentingan bersama atau gerakan mencapai tujuan bersama atau gerakan bersama melalui tindakan kolektif (action collective) diluar ruang lingkup lembaga- lembaga yang mapan.

Hal ini dapat dilihat dari pengorganisasian masyarakat-masyarakat Mandau dan Pinggir yang memperjuangkan secara kolektif untuk mewujudkan Kabupaten Mandau atau Kota Duri. Aktifitas gerakan ini dilahirkan sebagai kebutuhan akan wadah perjuangan masyarakat yang lebih besar. Dimulai sejak tahun 1999, yang merupakan titik awal perjuangan. Perjuangan masyarakat untuk membentuk Daerah Otonom Baru didasarkan pada dua aspek yaitu kesejahteraan (historis), rentang kendali dan ketimpangan pembangunan.

Pada umumnya kondisi Kota Duri (Mandau dan Pinggir) apabila dilihat dari prosedur pembentukan Daerah Otonom Baru sudah memenuhi syarat dan ketentuan, seperi luas wilayah, jumlah penduduk dan pendapatan asli daerah yang menopang pembiayaan sebagai Daerah Otonom Baru. Masyarakatnya memiliki peluang untuk menjadi lebih sejahtera yang ditunjukkan dengan tingkat Indeks Pembangunan Manusia (IPM) yang cukup baik.

Patut diakui, dalam pembentukan Kabupaten Mandau atau Kota Duri masih terdapat beberapa penghambat yakni kondisi wilayah Mandau yang masih terdiri dari dua kecamatan definitif, meskipun dua kecamatan lagi masih dalam proses. Kemudian tidak adanya rekomendasi dari Kabupaten Induk sehingga sampai saat ini belum terwujud. Ditambah lagi kurang komitmen para aktor dalam memperjuangkan pembentukan Daerah Otonom Baru.

Keinginan masyarakat di wilayah ini untuk melakukan pemekaran selama kurun waktu 15 tahun belum terealisasi, dikarenakan adanya dukungan setengah hati dari elit politik, sehingga keinginan masyarakat terkesan dimanfaatkan oleh segelintir elit politik dan pemerintah daerah yang berkuasa untuk mewujudkan kepentingan-kepentingan politik para elit politik sehingga menyebabkan per- 
Tersedia Online di http://journal.unismuh.ac.id/index.php/otoritas

Otoritas : Jurnal Ilmu Pemerintahan, 6 (1), April 2016, 58

tarungan kepentingan antara aktor-aktor gerakan dengan elit politik dalam merealisasikan terbentuknya Daerah Otonom Baru.

Pemekaran wilayah melibatkan banyak pihak di dalam pelaksanaannya. Setiap pihak yang terlibat memiliki kepentingan dan tujuan masing-masing. Kepentingan yang ada di dalamnya bisa berupa kepentingan pribadi, golongan atau pun kepentingan yang benar-benar bertujuan untuk mencapai kesejahteraan masyarakat secara keseluruhan (Farida dkk., 2010).

Embrio lahirnya KP2KM adalah sebenar-benarnya semangat perjuangan. Bukan persoalan kalah menang, sebab pemekaran adalah hak masyarakat yang dijamin oleh undang-undang. Setiap perjuangan pasti membutuhkan pengorbanan. Perjuangan yang cerdas memang membutuhkan kesabaran, termasuk menerima setiap perbedaan-perbedaan. Jika dilihat gerakan perjuang kabupaten Rokan Hilir, mereka melibatkan yayasan milik Tionghoa ke dalam arus pergerakan pembentukan Kabupaten Rokan Hilir. Bukan sebaliknya, untuk kepentingan tersembunyi, sebab, orang yang memiliki kepentingan tersembunyi pasti akan terancam.

Kondisi ini mencerminkan tindakan politik (Ramstedt dan Rufail, 2011) dimana rakyat mendapatkan kebebasan untuk bersuara dan menyatakan pendapat, kebebasan politik, mendirikan partai politik, termasuk mendirikan pemerintahan otonom melalui proses pemekaran daerah yang menjadikan Mandau sebagai daerah dengan potensi serta keberagaman yang dimiliki membutuhkan pemimpin yang merangkul semua lapisan tersebut.

Akhirnya penelitian ini menemukan dinamika gerakan sosial yang berwujud gerakan kolektifitas orang-orang di dalamnya untuk membawa atau menentang perubahan. Semua itu bisa terjadi disebabkan sifat masyarakat itu sendiri yang menginginkan perubahan hal ini dtandai dari pengorganisasian masyarakat-masyarakat Mandau dan Pinggir yang memperjuangkan secara kolektif untuk mewujudkan pemakaran daerah Kabupaten Mandau atau Kota Duri. Aktifitas gerakan ini dilahirkan sebagai kebutuhan akan wadah perjuangan masyarakat yang lebih besar.

\section{Kesimpulan}

Dari hasil penelitian dan pembahasan dapat ditarik kesimpulan bahwa dinamika gerakan sosial dan elit politik yang terjadi menunjukkan tindakan politik berupa berupa pergerakan dan perjuangan masyarakat Mandau untuk membentuk daerah otonom baru didasarkan pada dua aspek yaitu kesejahteraan dan historis, rentang kendali dan ketimpangan pembangunan. Kabupaten Mandau pada dasarnya memang layak menjadi daerah otonomi baru, mengingat kondisi geografis di Mandau dan Pinggir sangat luas, disamping besarnya sumber daya alam yang dimiliki. Kondisi Kota Duri (Mandau dan Pinggir) apabila dilihat dari prosedur pembentukan Daerah Otonom Baru sudah memenuhi syarat dan ketentuan, seperi luas wilayah, jumlah penduduk dan pendapatan asli daerah yang menopang pembiayaan sebagai Daerah Otonom Baru. Pergerakan yang paling konkit yaitu pengorganisasian masyarakat-masyarakat yang ditandai dengan lahirnya KP2KM yang merupakan semangat perjuangan Mandau dan Pinggir yang memperjuangkan secara kolektif untuk mewujudkan Kabupaten Mandau atau Kota Duri yang otonom.

\section{Ucapan Terima Kasih}

Ucapan terima kasih kami ucapkan kepada pihak yang mendukung kegiatan penelitian dan penulisan karya ilmiah ini, terutama civitas akademika STAIN Bengkalis Riau. 
Tersedia Online di http://journal.unismuh.ac.id/index.php/otoritas

Otoritas : Jurnal Ilmu Pemerintahan, 6 (1), April 2016, 58

\section{Daftar Pustaka}

Farida, A., Dharmawan, A. H., \& Tonny, F. (2010). Pertarungan Gagasan Dan Kekuasaan Dalam Pemekaran Wilayah: Studi Kasus: Kabupaten Bungo dan Kabupaten Tebo di Propinsi Jambi. Sodality: Jurnal Sosiologi Pedesaan, 4(2).

Kaho, J.R. (2012). Analisis Hubungan Pemerintah Pusat dan Daerah di Indonesia. Yogyakarta: PolGov.

Kurniawati, S. (2014). Pengaruh Pemekaran Provinsi Terhadap Pengembangan Wilayah Di Indonesia. Jurnal Perencanaan Wilayah dan Kota ASAPPK, 1 (1), 250-259.

Mirsel, R. (2006). Teori Pergerakan Sosial. Yogyakarta: Resist Book.

Ramstedt, M., Thufail, F.I. (2011). Kegalauan Identitas: Agama, Identitas dan Kewarganegaraan Pada Masa Pasca-Orde Baru. Jakarta: Gramedia Widiasarana.

Rifdan, R. (2010). Implementasi Kebijakan Pemekaran Daerah Dalam
Mendukung Integrasi Nasional Di Kabupaten Luwu Timur. Jurnal Administrasi Publik, 1 (1), 24-39.

Sugiyono, P. D. (2013). Metode Penelitian Manajemen. Bandung: Alfabeta, CV.

Susanti, S. 2014. Dampak Pemekaran Wilayah Terhadap Kesejahteraan di Kabupaten Lampung Utara. Jurnal Ekonomi Pembangunan. 3 (2). 249268. 